$$
\begin{aligned}
& \text { 福 谷和 久*1, 豊 島 史 郎*2 } \\
& \text { 豊秀喜*3, 山本淳*3 }
\end{aligned}
$$

\title{
Effects of Drawing Condition on Drawing Tension and Neck-Down Profile in Optical Fiber Drawing from Silica Glass Preform
}

\author{
Kazuhisa FUKUTANI*4, Shiro TOYOSHIMA, \\ Hideki YUTAKA and Atsushi YAMAMOTO \\ ${ }^{* 4}$ Mechanical Engineering Research Laboratory, Kobe Steel, Ltd., \\ 1-5-5 Takatsuka-dai, Nishi-ku, Kobe-shi, Hyogo, 651-271 Japan
}

\begin{abstract}
Numerical calculation of silica glass deformation in optical fiber drawing from preform has been carried out to reveal the effects of drawing condition on drawing tension and neck-down profile. Effects of drawing condition on drawing tension in optical fiber drawing are important in designing and setting of manufacturing process, because transmission characteristics of fiber is dependent on drawing tension when it is manufactured. Drawing condition is considered to have any effect on neck-down profile in drawing furnace, but it is not well known. This report presents numerical result of drawing tension and neck-down profile. It also shows how the distribution of value in drawing direction changes by drawing condition. The parameters of drawing condition are preform diameter, drawing velocity, heater temperature and its length. The ranges of them are $0.025 \sim 0.1 \mathrm{~m}, 10 \sim 25 \mathrm{~m}$ / s, $2400 \sim 2550 \mathrm{~K}$ and $0.05 \sim 0.2 \mathrm{~m}$, respectively.
\end{abstract}

Key Words: Computer Aided Analysis, Sensitivity Analysis, Industrial Machine, Optical Fiber, Drawing

\section{1. 精吾}

筆者らは石英系光ファイバ素線の紡系過程について, 母材の熱流動変形の数值計算を用いた検討を行ってい る. 前報 ${ }^{11)}$ 一゙は, 本研究の定常数值計算の手法を説明 し,一つの紡系条件について計算結果を示した.

光ファイバ素線紡系の生産性向上のため, 高速の紡 系, 大径母材の紡系, が従来から求められている。 こ のためには，母材をより速く，大きく変形させる必要 があるから，熱的な条件が一定のもとでは所定径の素 線をえるための紡糸張力が増加する. しかし他方で素 線の伝送特性を良好に維持するためには，紡糸張力を 一定に保つことが必要とされている. したがって紡系 の高速化，母材の大径化をしつつ，良好な伝送特性の 素線をえるためには，ヒータ温度や長さといった熱的 な条件をあわせて変更する必要がある.

\section{このようなことから，紡系張力とそれに影響寸る熱}

* 原稿受付 2003 年 8 月 7 日.

*1 正員, (株) 神戸製鋼所機械研究所( 3651 -2271 神戸市西区 高塚台 1-5-5).

*2 正員, (株) コベルコ科研 (\$ 660-0083 尼崎市道意町 6-32).

*3 (株) 神戸製鋼所産業機械部(画676-8670 高砂市荒井町新浜 2-3-1).

E-mail : k-fukutani@ rd.kcrl.kobelco.co.jp
的な条件は工程において重要であるが，これらを測定 することは困難である. 素線は細く，もろく，高速で 移動しているから，素線を破損させることなく紡系張 力を接触測定することは難しい. また工程では素線に 樹脂被覆を施した後に張力を付加している(2)ので，母 材にかかる真の張力は明らかではない，さらに紡系中 の母材や加熱炉の温度分布などの熱的な条件の測定は， 設備の制約から困難なことが多い.

以上のことから, 紡系の条件出しでは, 条件を変 更して紡系した後に, 素線の伝送特性を測定し, その 結果から所定の張力が付加されているか確認すること を多数綝り返す必要があるという問題がある. また炬 内のネックダウン形状は熱的な条件を含む紡系条件を 反映していると経験的に考えられているが，紡系条件 とネックダウン形状の関係は必ずしも明らかではない． これまでの光ファイバ素線の紡系過程の定常状態に関 する研究 ${ }^{(3)-(8)}$ の紡系条件は, 母材径が小さく, 紡系速 度が低い条件に限られており(1), 現在の紡系工程に対 応する紡系条件を含む幅広、筑囲について, 紡系条件 と紡系張力およびネックダウン形状の関係を調べた研 究はない.

本報告では，前報(1)の計算手法をもちいたパラメー 
タスタディにより, 紡系条件と紡系張力およびネック ダウン形状の関倸を整理するとともに，紡系条件によ り諸量の分布がどのように変化するかを示す。これら を示すことは, 上述の紡系条件出しを合理的に行うた めの材料としての意義が大きいと考える.

\section{2. 钯昂}

アルファベット $\quad D:$ 直径 $[\mathrm{m}], F:$ 張力 $[\mathrm{N}]$, $L:$ 紡系方向長さ $[\mathrm{m}], T:$ 絶対温度 $[\mathrm{K}], W:$ 紡系方 向速度 $[\mathrm{m} / \mathrm{s}], z:$ 紡系方向座標 $[\mathrm{m}]$

$$
\text { ギリシャ文字 } \quad \eta: \text { 粘性率 }[\mathrm{Pa} \cdot \mathrm{s}]
$$

添え字 $\quad 0$ : 計算領域入り口, $c:$ 母材中心, $f$ : 計 算領域出口, $g:$ 雾囲気ガス, $h:$ 炉壁面最高温領域 (ヒータ) $, m:$ 断面平均, $s:$ 母材表面, $w$ : 炉壁面

\section{3. 尌策手法}

基礎式は連続の式，運動量の式およびエネルギの式 である. 連続の式および軍動量の式は, 紡系方向速度, 紡系方向に垂直な断面積, および引張り粘性率をもち いて紡系方向の一次元で, エネルギの式は軸㸚称二次 元であつかった. 計算の手法, 計算領域の分割数など は前報(1) と同様である.

\section{4. 計算集件}

紡系条件を表変数は, 母材直径 $D_{b}$ 紡系速度 $W_{f}$ 炬壁面最高温領域 (ヒー夕領域) の温度 $T_{h}$ およびそ の長さ $I_{n}$ とした. それぞれ想定される範囲を $0.025 〜$ $0.1 \mathrm{~m}, 10 \sim 25 \mathrm{~m} / \mathrm{s}, 2400 \sim 2550 \mathrm{~K} お よ ひ ゙ ~ 0.05 〜 0.2 \mathrm{~m} \mathrm{として}$ 計算を行った. 炉内径 $D_{w}$ と母材直径 $D_{0}$ の差は $0.01 \mathrm{~m}$

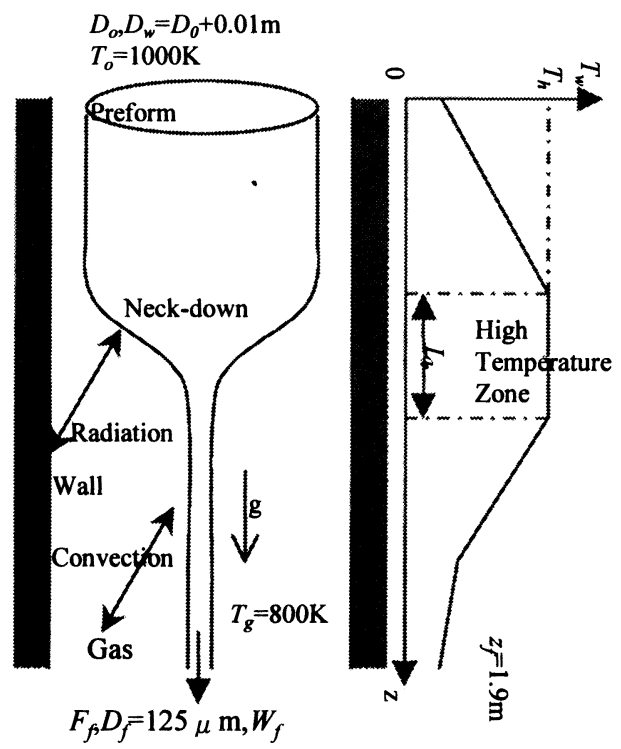

Fig. 1 Computational domain and drawing condition
で一定とした. ヒータ長さ $L_{h}$ を変更する場合には, その上端の位置を固定して長さを変更し，その下端か ら下流の壁面温度 $T_{w}$ の分布は, 下端からの距離によ り決まるとした。

\section{5. 計算結果および考寮}

5.1 就系張力への材直径 $D_{0}$ と紡采張力 $F_{f}$ の関係を図 2 に示す. 紡系張力は母材直径に対して 一次関数的に増加した.

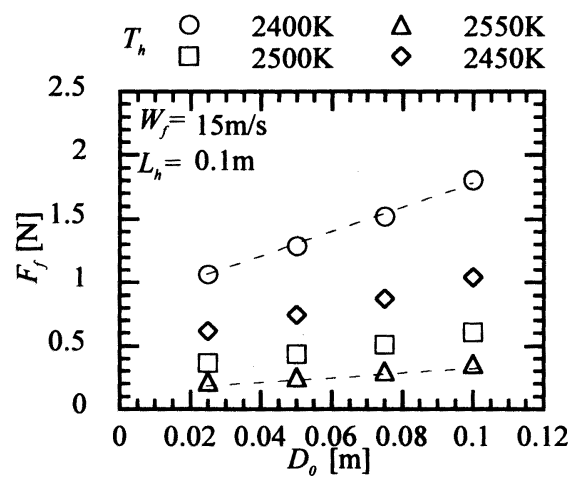

Fig. 2Drawing tension vs. preform diameter

つぎに紡系速度と紡系張力の関係についてみる.こ の関倸については Pakand Runk ${ }^{(3)}$ および Vasiliev ら ${ }^{(5)}$ が計 算結果を示している。これらの報告では, 紡系張力は 紡系速度にほほ比例し, 紡系速度の増加につれて比例 関係とのずれが拡大している. しかし前者は下方に, 後者は上方にずれており方向が異なっている. なおネ ックダウン形状とその部分の温度分布が紡系速度によ らず一定であるとすると, 紡系張力は紡系速度に比例 することを基礎式から解析的に確認することができる.

本計算により得られた紡系速度 $W_{f}$ と紡系張力 $F_{f}$ の 関係を図 3 に示す. 図中の破線は比例関係を表す直線 である. 紡系張力は紡系速度にほぼ比例し, 紡系速度 の増加につれて，比例関係から下方にずれた。これは

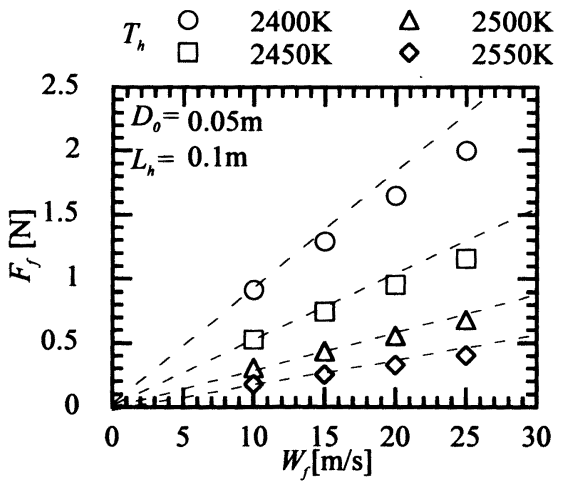

Fig 3Drawingtension vs dawing velocity 
Paek and Runk ${ }^{(3)}$ と同様の傾向であった. これは後に示す ように，紡系速度の上昇にともなって，母材温度の降 下寸る領域において，母材の高温，低粘性の領域が下 流側に広がるためである.

つぎにヒータ温度 $T_{h}$ およびヒー夕長さ $L_{h}$ と紡糸張 力 $F_{f}$ の関係を図 4 および 5 にしめす. 紡系張力はこれ らの值と反比例的な関係となった.

図2から5によると，ヒータ温度 $T_{h}$ が低いほど紡系 張力が高く, 条件による紡系張力の差も大きいことが 分かる. これは母材の温度が低いほど，母材の粘性率 とその温度依存性が大きいため, 条件による母材の温 度分布の変化が，紡系張力の差としてあらわれやすく なるためである.

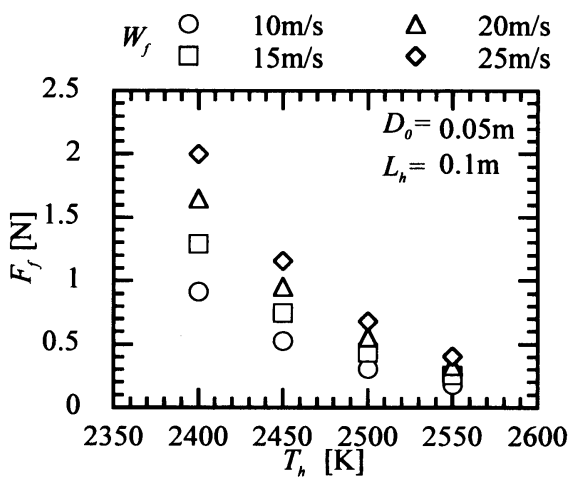

Fig 4Drawing tension vs hedertemperare

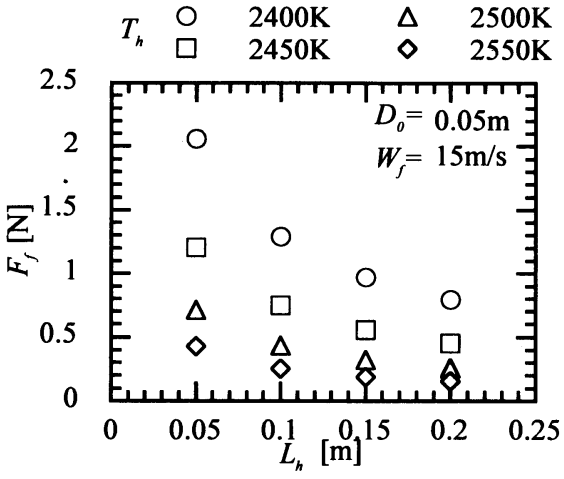

Fig 5 Drawingtension vs heder length

5.2 ネックダウン形状への影各パラメー タのネックダウン形状への影響を, 基準条件との直径 の差の分布からみていく. 図6から 9に各パラメータ を変更したときの基淮条件 Case （a ）[母材径 $D_{0}=0.05 \mathrm{~m}$, 紡系速度 $W_{F}=15 \mathrm{~m} / \mathrm{s}$, ヒー夕温度 $T_{h}=2450 \mathrm{~K}$, ヒー夕長さ $\left.L_{n}=0.1 \mathrm{~m}\right]$ との直径の差 $\Delta D$ の分布の変化を示す. 図中 の波線は Case (a))直径の分布である. また縦軸に平 行な破線はヒータ長さ $L_{n}=0.1 \mathrm{~m}$ の時のヒータ上端 $\mathrm{HU}$ と下端HLの位置を示す。
図 6 によると母材直径 $D_{o}$ が大きくなるのにともな って, ヒ一タ上流功ヒータ下端 HL 付近にかけ付直 径差 $\Delta D$ が大きくなっている.この差はヒー夕領域 （HUから HL）では上端 HU付近で最大であり，下端 HLから下流ではきわめて小さかった. これは下端 HL から下流の母材温度は母材直径 $D_{0}$ にほとんど依存し ないためである. 上端 HU での直径差は最大で $0.01 \mathrm{~m}$ 程度であった。
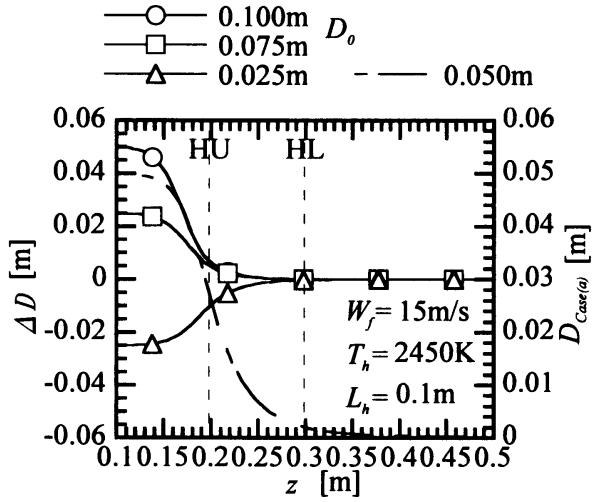

Fig 6Effects of preform diameteronneck-down profile

つぎに紡系速度 $W_{f}$ が上昇するにつれて（図 7）， ヒータ付近の直径差 $\Delta D$ が大きくなった．その差は七 一夕上端 $\mathrm{HU}$ 付近において最大となり，下流に向かっ て減少したが，ヒータ下端 HL より下流においても差 が認められた。 上端 $H U$ 付近の直径 Dが抗大するのは, 母材半径方向の温度差が大きくなり断面平均の粘性率 が上昇するためである. 下端 HLよりも下流について は，母材が高温，低粘性に保たれる領域が下流側に拡 大寸るためである. これらの分布の変化は後に示寸. 上端 HUおよび端 HL 付近の直径差は，それぞれ最 大で $0.004 \mathrm{~m}$ 程度および $0.001 \mathrm{~m}$ 程度であった.
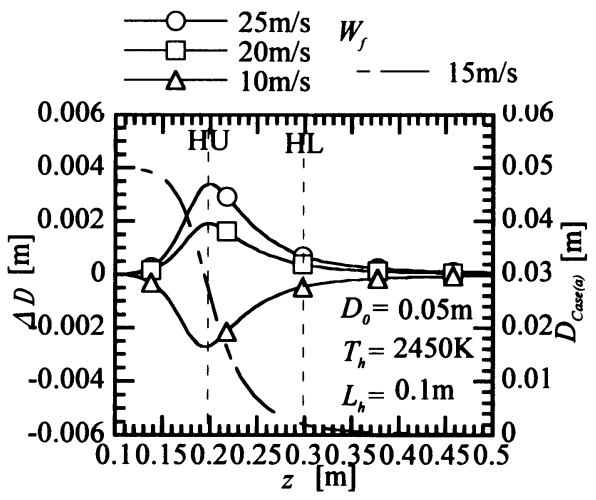

Fig 7Effects of drawing velocityonnedk-down profile 
ヒータ温度 $T_{h}$ が上昇すると（図 8)，ヒー夕付近の 直径差 $\Delta D$ が減少した. その差はヒータ上端 $\mathrm{HU}$ 付近 において最大であり，下端 HL 付近では差は比較的小 さかった. このようにヒータ領域の直径が減少するの は, ヒータ温度の上昇にともなって, この領域の母材 温度が上昇し, 粘性率が低下するためである. しかし このとき下端 HLより下流では温度上犁は小さいため, 直径の差は比較的小さかった. 上端 HU 付近の直径差 は最大で $0.004 \mathrm{~m}$ 程度であった.

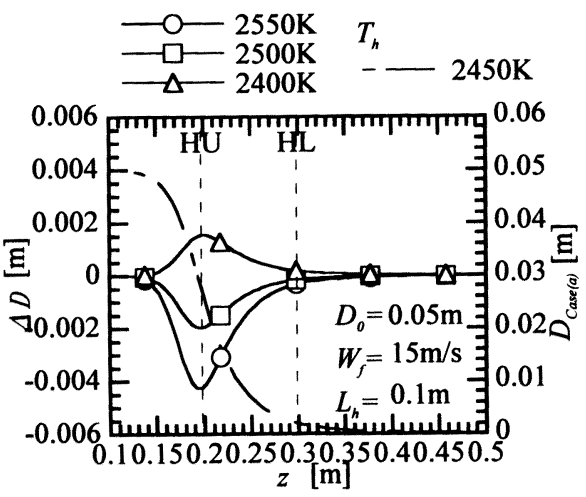

Fig 8Effect of heater temperatureanneck-down profile

最後にヒー夕長さ $L_{h} か ゙$ 長くなると（図 9)，ヒー夕 領域の直径差 $\Delta D$ が大きくなるとともに, 差が認めら れる領域が下流側に拡大した。 これは後に示すように ヒー夕長さに対応して，母材の高温領域が拡大するた めである. 図 7および8ではヒータ上端 HU付近で条 件による直径差が最大であったが，図9ではそれが最 大となる位置も変化している. このことから他のパラ メータに比べて，ヒータ長さの変化によるネックダウ ン形状の変化は特徽的であるといえる. このときの直 径差は最大で $0.005 \mathrm{~m}$ 程度であった。
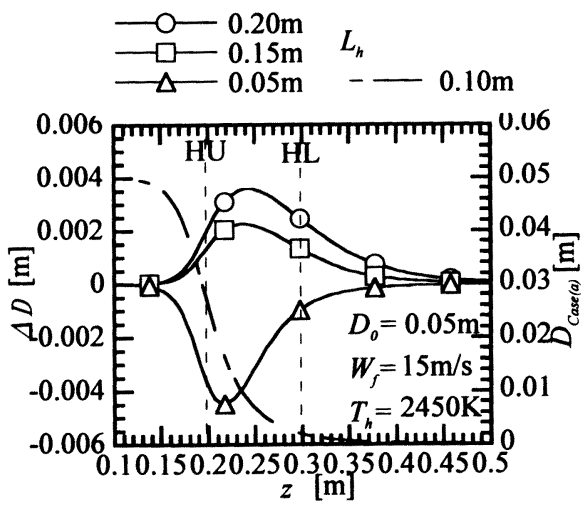

Fig 9Effect of heater lengthonnedk-down profile
5.3 諸量の分布の变化 四つの変数から紡系 速度 $W_{f}$ およびヒータ長さ $L_{h}$ の二つを取り上げ, これ らにより諸量の分布がどのように変化するかをみてい く.ここで紡系速度は紡系張力との関係が既存文献 ${ }^{(3)}$ (5)と比較できるため, ヒータ長さは前節においてネッ クダウン形状への影響が特街的であったため, それぞ

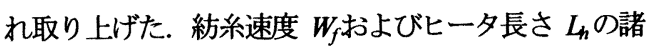
量の分布一の影響をそれぞれ図 10 およひ図 11 に示す。 炉壁面温度 $T_{w}$ は計算条件として仮定した分布である. 図中の記号の NU, NL，HU，HLおよびVGMは前報(1) と同様にそれぞれ Case (a) のネックダウン領域の上流 端, 下流端，ヒー夕領域の上流端，下流端および速度 勾配の最大位置を示寸。

まず母材中心温度 $T_{c}$ およひ断面平均粘性 $\eta_{m}$ の分布 に着目すると, いずれの条件についても, ネックダウ ン領域（NUから NL）をつぎの領域 Iから III に分け ることができると考えられる.

領域I：母材が加熱され温度が上昇し, 粘性率が低下 する領域 (NUから HU付近)

領域 II : 温度および粘性率がほぼ一定に保たれる領域 (HU 付近加 HL 付近)

領域 IIII : 母材が泠却され温度が降下し, 粘性率が上昇 する領域 (HL付近加 NL)

ここで領域 IIでは，粘性率およひ張力がほぼ一定であ るから, 直径が指数関数的に减少している(1).

紡系速度 $W_{f}$ が増加すると（図 10），領域 IおよびII の母材中心温度 $T_{c}$ およひ断面平均粘性率 $\eta_{m}$ の分布は ほとんど変化していないが, 領域 III においてこれら の勾配が小さくなっている. このとき直径 $D$ はほぼ 全領域において大きくなるが, その変化の割合は領域 IIIにおいて最も大きい.これは紡糸速度の上昇にとも なって, 主に領域 III の平均粘性率 $\eta_{m}$ が低下している ためである. これらのことから, 紡系速度の上昇にと もなって, 主に領域 III の高温, 低粘性の領域が拡大 し, この領域の直径が拡大して, 紡系速度と紡系張力 の関係が図 3 のように比例関係から下方にずれるもの といえる.

ここで図 7のネックダウン形状の差について考える. 紡系速度が上昇すると, 半径方向の温度差 $\left(T_{s} T_{d}\right)$ が 拡大しており，その幅はヒータ上端 HUの上流におい て大きい. このため, この領域の断面平均の粘性率が 上昇し, 直径の減少勾配 $(-d D / d)$ が小さくなる. 七 一夕上端 HU 付近の勾配は領域内で最大である(1)ため, 勾配の変化が図 7 の上端 HU 付近の直径の差として表 れている.

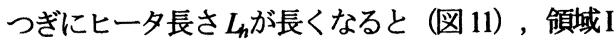



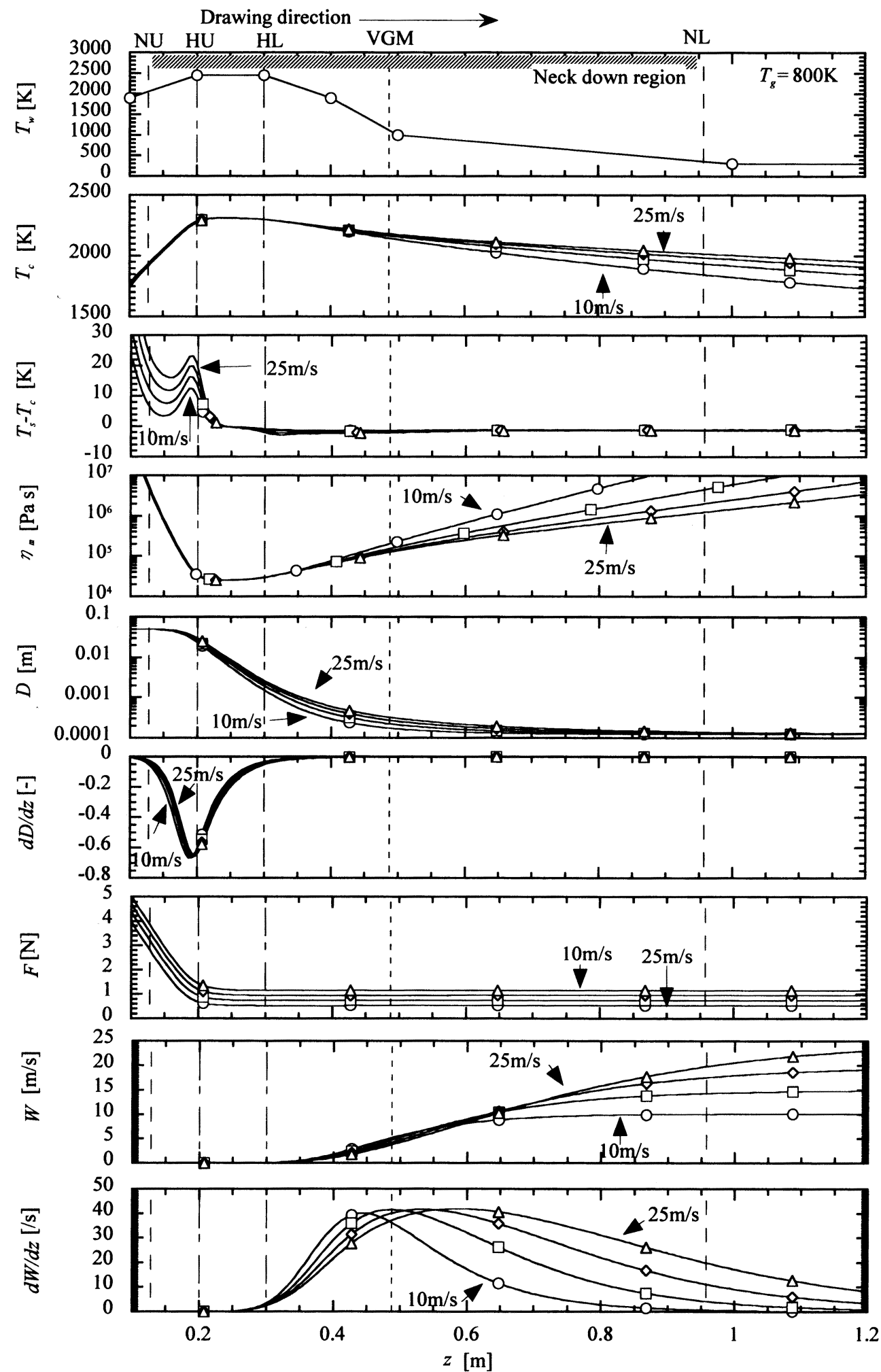

Fig. 10 Effects of drawing velocity on drawing process 

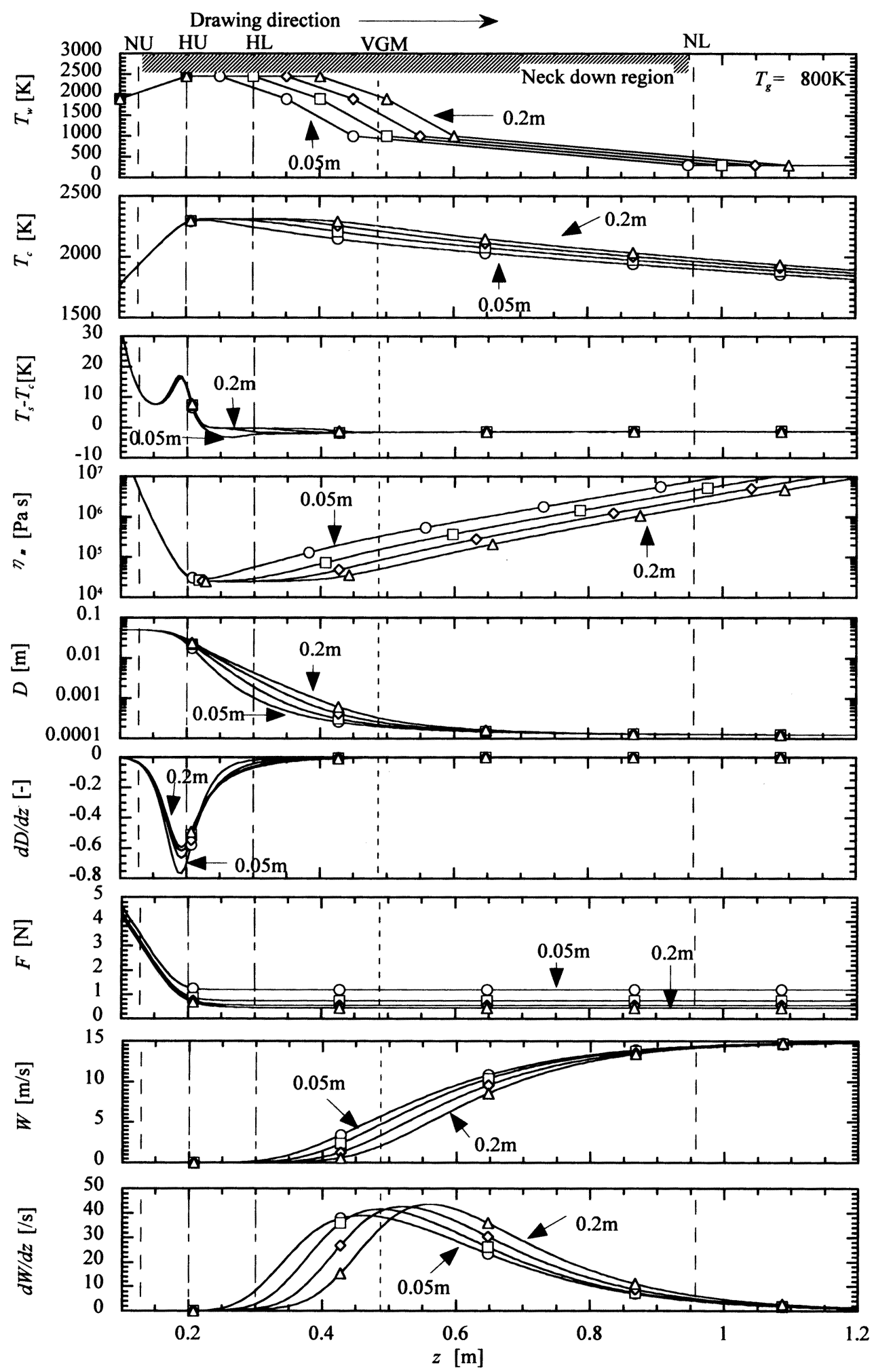

Fig. 11 Effects of heater length on drawing process 
の母材中心温度 $T_{c}$ およひ断面平均粘性率 $\eta_{m}$ の分布, および領域 III のこれらの勾配はほぼ一定であるが, 領域 IIがヒータ長さと対応して長くなる. このとき直 径 $D$ はほぼ全領域において大きくなるが，その差は 領域 IIにおいて大きい，これは領域Iが長くなるのに ともなって, ヒータ上端 $\mathrm{HU}$ 付近の直径の減少勾配 $(-d D / d z)$ が小さくなるためである. このように図 9 の特徵的な直径の差が生じている.

筆者らは母材直径 $D$ が小さい領域の母材変形の程 度を表す量として速度勾配 $d W / d z$ の分布に注目してい る(1). 本報告では, 紡系条件によるその分布の変化を 指摘しておく．まず紡系速度 $W_{f}$ が増加したとき（図 10），速度勾配が増加し始める位置はほとんど変わら ないが，それが卓越する領域は下流に広がる．それが 最大となる位置は下流に移動し, 最大值は若干大きく なる. つぎにヒータ長さ $L_{h}$ が長くなると（図 11）， 速度勾配が増加し始める位置が下流に移動し, それに ともなって卓越する領域と最大位置も下流に移動する. このとき最大値は若干大きくなる.ここで紡系速度お よびヒー夕長さによらず, 速度勾配の最大位置の直径 は $200 \mu \mathrm{m}$ 程度であり, 前報に述べた近似的な算出方 法(1)が依然として有効であることが確認できる. 速度 勾配の分布の重要性については外径変動と関連づけな がら次報において詳しく報告する.

\section{6. 䊅言}

本報告では，前報(1)の計算手法をもちいて，石英系 光ファイバ素線の紡系条件が紡系張力およびネックダ ウン形状に与える影響と, 紡系条件による諸量の分布 の変化を, 紡系の条件出しを合理的に行うための材料 として示した.

紡系条件と紡糸張力およびネックダウン形状の関係 について次のような結果を得た.

(1) 紡系張力は母材直径に対して一時関数的に増加す る.

（2）紡系張力は, 紡系速度にほぼ比例して増加し, 速 度の上昇にともなって比例関倸から下方にずれる.
これは母材温度の降下領域において高温，低粘性 の領域が下流側に広がるためである.

(3) 紡糸張力は, ヒー夕温度およびヒー夕長さと反比 例的な関係にある.

（4）(1)から(3)のときの紡糸条件による紡糸張力の差は， ヒータ温度が低いほど，大きくなる。

（5）母材径が大きくなると，ヒータ上流からヒータ下 端にかけて直径が拡大する. しかしヒータ下端付 近から下流では直径差はほとんどない，

(の) 紡系速度の上昇にともない, ヒー夕付近の直径が 拡大寸る. このときの直径差は, ヒータ上端付近 において最大となり, 下端から下流においても差 が認められる.

(7) ヒ一夕温度が上昇すると, ヒ一夕付近の直径が小 さくなる.このときの直径差は, ヒータ上端付近 において最大となり，下端から下流では比較的小 さい.

（8）ヒータが長くなると，ヒータ付近の直径が大きく なり, 直径差の認められる領域が拡大寸る.これ はヒータ長さに対応して, この付近の母材の高温 領域が広くなるためである.

次報ではこれまでの計算結果をもとにして, 素線の 外径変動の数值計算を行う.

\section{考考文献}

（1）福谷ほか 3名，機䇎 C編，69(2003), 1670-1677.

(2) Murata H., Handbook of Optical Fibers and Cables 2nd ed, Maroel Dekker, Inc., (1990), 101-108.

(3) Pack U.C. and Ruck, R. B., J. Appl. Phys, 49(1978), 4417-4422.

(4) Homsy, G. M and Walke, K., Glass Tectmology, 20(1979), $20-26$.

(5) Vasiliev, V.N. et al, Glass Technology, 30(1989), 83-90.

(6) Lee, S.H.K. and Jaluria, Y., ASME/SME Thermal Engineering Conference, 4(1995), 8593.

(7) Choudhry, S. R etal, ASME HTD, 306(1995), 23-32.

(8) Lee, S. H-K. and Jaluria Y, Joumal of Heat Transfor, 118(1990), 350-358. 